\title{
Anthocyanin, nutrient contents, and antioxidant activity of black rice bran of Oryza sativa L. 'Cempo Ireng' from Sleman, Yogyakarta, Indonesia
}

\author{
Pratiwi Apridamayanti ${ }^{1}$, Rarastoeti Pratiwi ${ }^{2}$, Yekti Asih Purwestri ${ }^{2}$, Woro Anindito Sri Tunjung ${ }^{2}$, and Rumiyati ${ }^{3, *}$ \\ ${ }^{1}$ Faculty of Medicine, Universitas Tanjungpura, Jalan Prof. Hadari Nawawi, Pontianak 78121, Kalimantan Barat, Indonesia \\ ${ }^{2}$ Faculty of Biology, Universitas Gadjah Mada, J. Teknika Selatan, Sekip Utara, Sinduadi, Mlati, Sleman, Daerah Istimewa Yogyakarta 55281, \\ Indonesia \\ ${ }^{3}$ Faculty of Pharmacy, Universitas Gadjah Mada, Sekip Utara, Daerah Istimewa Yogyakarta 55281, Indonesia \\ *Corresponding author: rumiyaris@ugm.ac.id
}

\begin{abstract}
The chemical contents and health benefits of black rice bran of some rice cultivars have been investigated. However, there has been little research on the 'Cempo Ireng' cultivar from Sleman, Yogyakarta. The aim of this present study was to determine the anthocyanin, antioxidant activity, and macro- and micronutrients contents of black rice bran from this local cultivar. The anthocyanin in the black rice bran was extracted using the maceration method with methanol as a solvent. The extract obtained was separated through a preparative thin layer chromatography (TLC) of silica GF254 and a mobile phase composed of n-butanol, acetic acid, and water. Two fractions were collected and analyzed for the anthocyanin content. The preparative TLC spots were separated for further detection and measurement of cyanidin 3-O-glucoside using HPLC followed by LC-MS. The antioxidant activity of the fractions were measured using the DPPH free radical scavenging method. The results showed that the anthocyanin in fraction 1 was identified as cyanidin 3-O-glucoside (66.1 $\pm 10.6 \mu \mathrm{g} / \mathrm{g})$. The $\mathrm{IC}_{50}$ of fractions 1 and 2 were 200.96 and $218.36 \mu \mathrm{g} / \mathrm{mL}$, respectively. Analysis of the macro- and micronutrients revealed that the black rice bran of 'Cempo Ireng' had nutrient contents comparable with other rice cultivars. Therefore, this local black rice bran can be used as a source of antioxidants and macro- and micronutrients.
\end{abstract}

KEYWORDS anthocyanin; antioxidant; black rice bran; nutrient contents

\section{Introduction}

Black rice is becoming more popular and is now consumed as a functional food due to its health benefits. Black rice contains macro- and micronutrients such as carbohydrate and protein, and the micronutrients such as vitamins and minerals which are higher than those in white rice. Kristamtini et al. (2012) and Ichikawa et al. (2004) reported that the mineral content of black rice such as Fe, Zn, Mn and $\mathrm{P}$ is higher than white rice, and that the mineral content in black rice depends on the variety and type of soil where it is grown. In addition to the nutrient contents, black rice also contains bioactive compounds including anthocyanin.

The anthocyanin component in black rice is known to have health benefits such as antioxidant activity against ROS (Park et al. 2008), reducing oxidative stress on mice (Xia et al. 2006), anticancer activity (Hyun and Chung 2004) and anti-inflammatory activity (Tsuda et al. 2003). Black rice has better physical properties than white rice. It is a soft and fragrant rice due to the amylose content in black rice of about $22.97 \%$. The other phytochemical contents are beta-caroten and anthocyanin, about 804.16 mg/100 g and 393.93 ppm respectively (Kristamtini and Purwaningsih 2009). In Indonesia, several local black rice cultivars have been studied, however, their phytochemical content and health benefits still need further investigation (Pratiwi and Purwestri 2017).

The previous studies showed that the black rice dietary of local cultivar 'Cempo Ireng' affected an increase in HDL (High-Density Lipoprotein) in hyperlipidemic rats and decreased LDL (Low-Density Lipoprotein) in hyperlipidemic rats, and the level of cholesterol concentration decreased significantly (Pratiwi et al. 2014). The methanolic extract fraction of rice bran of this cultivar is also a potential candidate for preventing the growth of cervical cancer HeLa cells (Pratiwi et al. 2015). Furthermore, the black rice bran extracts from different cultivars ('Toraja', 'Woja Laka' and 'Cempo Ireng') have a different response cytotoxic activity in different cells, i.e. HepG2 cells, Raji cells and Vero cells (Rukmana et al. 2016).

Rice bran is a by-product of rice milling and consists of the pericarp, seed coat, nucellus and aleurone (Juliano 1985). The aleurone layer in black rice has been reported to contain anthocyanin as well. The content of antho- 
cyanin in black rice has been reported by Ryu et al. (1998) and Yoshimura et al. (2012) and, based on these studies, the black rice is rich in anthocyanin in the aleuron layer. Xia et al. (2006) reported that consumption of aleurone layer extracts can reduce cholesterol and triglyceride levels in the blood of mice deficient in Apo-E. The type of anthocyanins in the aleurone layer are known as cyanidin 3-O-glucoside and peonidin 3-O-glucoside.

This study was conducted with the aim of determining anthocyanin, quantification of total anthocyanin, antioxidant activity of the extract fraction of black rice bran and to measure the protein, carbohydrate, lipid, minerals and water contents in the black rice bran 'Cempo Ireng'. The result of this study is expected to provide more information on anthocyanin and nutrient contents in black rice bran. Furthermore, this black rice bran can be developed as an alternative source of potential functional foods.

\section{Materials and methods}

\subsection{Plant material}

Black rice 'Cempo Ireng' was described by Pratiwi et al. (2015). This rice was obtained from Sayegan, Sleman, Yogyakarta, Indonesia.

\subsection{Chemicals}

Methanol, $\mathrm{HCl}$, acetic acid, phosphoric acid, formic acid, n-butanol, silica powder F 254 (Merck) and standard of Cyanidin 3-O-glucoside (Polyphenols Laboratories AS 1201-1), $\mathrm{H}_{2} \mathrm{SO}_{4}, \mathrm{HNO}_{3}$, solution mixture of boric acid with $1 \%$ solution of methyl bromo cresol green and red, $\mathrm{K}_{2} \mathrm{SO}_{4}, \mathrm{~K}_{3} \mathrm{Fe}(\mathrm{CN})_{6}, \mathrm{Na}_{2} \mathrm{~S}_{2} \mathrm{O}_{3}, \mathrm{Na}$-tungstate, $\mathrm{KCl}, \mathrm{KI}$, $\mathrm{ZnSO}_{4} .7 \mathrm{H}_{2} \mathrm{O}$, selenium, Iod $2 \%$, amylase standard, nhexane, petroleum ether, petroleum benzine, Benedict solution, glucose standard, Nelson solution, alcohol 80\%, $\mathrm{CaCO}_{3}$, Na-dried oxalate (Merck), standard minerals Ca, $\mathrm{P}$, and Fe (Sigma Aldrich), 2,2-diphenyl-1- picrylhydrazyl (DPPH) (Sigma-Aldrich).

\subsection{Sample preparation}

Black rice bran was powdered with a sample mill cyclotec machine and sieved through a 100 mesh sieve.

\subsection{Analysis of anthocyanins}

The total anthocyanin content in the rice bran was measured by the pH-differential method (Lee et al. 2005). The rice bran was dissolved in KCL buffer $\mathrm{pH} 1.0$ and buffer $\mathrm{CH}_{3} \mathrm{COONa} \mathrm{pH} 4.5$ and absorbance of the solution was measured using a spectrophotometer at 520 and 700 $\mathrm{nm}$. The content of total anthocyanin was calculated with the formula:

Total anthocyanin $\mathrm{mg} / \mathrm{L}=$

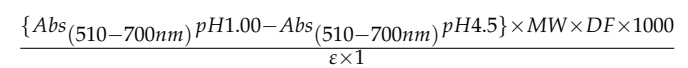

where $\varepsilon$ is the molar extinction of cyanidin 3-O-glucoside (26.900 L $\left.\times \mathrm{mol}^{-1} \times \mathrm{cm}^{-1}\right)$; MW is the molecular weight of cyanidin 3-O-glucoside (449.2); DF is the dilution factor; and 1 is cuvette thickness $(1 \mathrm{~cm})$.

The anthocyanin fraction was prepared using the modified methods of Abdel-Aal et al. (2006) and Kim et al. (2008). Three g of black rice bran was extracted using the combination of methanol: $\mathrm{HCl} 1 \mathrm{~N}(85: 15)$. Analysis of the chemical content of the extract was carried out using analytical TLC silica F254 and was then separated using preparative TLC silica GF254 as the stationary phase and n-butanol:acetic acid:water (4:1:5) as the mobile phase. The results of preparative TLC were detected under visible light and UV $366 \mathrm{~nm}$ and the spot was marked. The spot result in preparative TLC was separated and dissolved in methanol: $\mathrm{HCl}(85: 15 \mathrm{v} / \mathrm{v})$ and then characterized using HPLC (Hitachi UV-Vis detektor L2420) and LC-MS (Accela PDA, autosampler 1250 Orbitrap Thermo exative). The mobile phase of HPLC was phosphoric acid:acetonitrile (80:20), stationary phase was C-18 column (cromasil 250x4.6 mm) and mobile phase of LC-MS corresponding to Abdel-Aal et al. (2006) research was formic acid 6\% (A) dan methanol 100\% (B) in gradient flow rate, stationary phase was $\mathrm{C}-18$ column (hypersil bold $50 \times 2.1 \mathrm{~mm})$. HPLC data were compared with the retention time of each fraction with standard cyanidin 3-Oglucoside and followed by analysis using LC-MS to study the $\mathrm{m} / \mathrm{z}$ of fractions and compared with the $\mathrm{m} / \mathrm{z}$ theoretical compound of cyanidin 3-O-glucoside.

\subsection{The activity of radical scavenging assay against 2.2-diphenyl-1-picrylhydrazyl (DPPH)}

The antioxidant activities of the fractions from viscous rice bran extract were carried out using DPPH scavenging radical activity. One $\mathrm{mL}$ of $0.1 \mathrm{mM}$ solution of $\mathrm{DPPH}$ in methanol was mixed with the solution of the fraction of viscous rice bran extract by dissolving four concentrations of 50, 100, 250 and $500 \mu \mathrm{g} / \mathrm{mL}$, and methanol was added to the solution upto $5 \mathrm{~mL}$. The solution was incubated for $30 \mathrm{~min}$ and then absorbance was measured with the spectrophotometer at $515 \mathrm{~nm}$, as was carried out by Brand-Williams et al. (1995) and Kikuzaki et al. (2002).

\subsection{Analysis of macro- and micronutrients}

Carbohydrates (AOAC), proteins (Kjeldahl), lipids (Shoxtec Analyzer), amylase (Spectrophotometer) and minerals $\mathrm{Ca}, \mathrm{P}$ and Fe (ICP-MS) were analyzed using the standard method AOAC 944.02. All data is presented as the mean \pm standard deviation.

\section{Results and discussion}

\subsection{Separation and identification of anthocyanin}

Black rice bran of 'Cempo Ireng' Sayegan, Yogyakarta was extracted by the maceration method using methanol and $1 \mathrm{~N} \mathrm{HCl}$ in the ratio 85:15 v/v. The resulting filtrate 


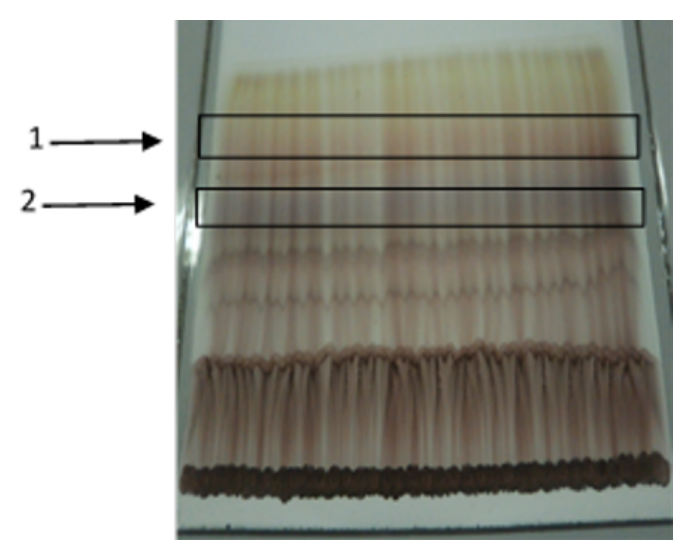

(a)

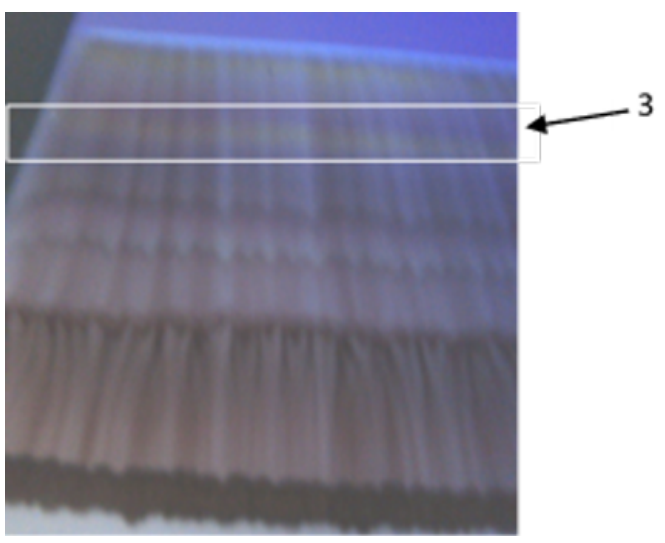

(b)

FIGURE 1 Crude extract black rice bran with thin layer chromatography preparative silica 254 with stationary phase and mobile phase $\mathrm{n}$ butanol:acetic acid:water (4:1:5). (a) Spot lines detection with visible light; and (b) with UV $366 \mathrm{~nm}$. Fractions 1, 2, and 3 are in the direction of the arrow.

was then separated using liquid-liquid partition and by using n-hexane as the solvent to separate nonpolar compounds such as lipids. About $120 \mathrm{~g}$ of the sample of black rice bran was extracted, resulting in $19.4 \mathrm{~g}$ of viscous extract. The amount of the yield of viscous extract is $16.2 \%$. The determination of the total anthocyanin content using $\mathrm{pH}$ differentiation method in black rice bran is obtained $8.2 \pm 0.8 \mathrm{mg} / \mathrm{g}$.

Viscous extract was separated with a preparative thin layer chromatography (TLC) using the mobile phase nbutanol:acetic acid:water (4:1:5). The profile of separated fractions on thin layer chromatography can be seen in Figure 1 which shows three fractions of viscous extract. The result of fraction separation is shown in the direction of the arrow in Figure 1. The data of the separation results of the viscous extract with thin layer cellulose chromatogram can be seen in Table 1. The retention factor (hRf) of each fraction has a different spot according to UV $254 \mathrm{~nm}$ and visible light detections. The retention factor is a quantitative indication of how far a molecule of a compound is brought into the mobile phase. The data from Table 1 shows the comparison of the retention factor of each fraction with a marker compound. In this study we used cyanidin 3O-glucoside as a marker. Table 1 shows that fraction 1 has a similar retention factor with cyanidin 3-O-glucoside, which means that quantitatively fraction 1 has similarities in chemical properties with cyanidin 3-O-glucoside. Frac-

TABLE 1 Chromatogram of viscous extract separated with cellulose thin layer chromatography as a stationary phase.

\begin{tabular}{|c|c|c|c|c|}
\hline No. & Compound & hRf & Visible light & UV 254 \\
\hline 1 & $\begin{array}{l}\text { Cyanidin 3-O- } \\
\text { glucoside }\end{array}$ & 0.56 & Magenta & Damping \\
\hline 2 & Fraction 1 & 0.56 & Magenta & Damping \\
\hline 3 & Fraction 2 & 0.71 & Magenta & Damping \\
\hline 4 & Fraction 3 & 0.81 & Yellow & $\begin{array}{l}\text { Yellow Flores- } \\
\text { cence }\end{array}$ \\
\hline
\end{tabular}

tions 2 and 3 have different hRf's.

The data from this study can be seen in Table 1 and is continued in the characteristics of fractions 1 and 2. The election of fraction 1 based on qualitative test (hRf) with TLC separation indicated that fraction 1 is cyanidin 3-Oglucoside.

\subsection{Characterization of BRB anthocyanin with HPLC and LC-MS}

The HPLC data shows a typical chromatogram for each fraction (Figure 2 and 3). The data was obtained from the retention time and area from each fraction. Chromatograms of fractions 1 and 2 are presented in Figure 2 and 3. From these results we can choose which fraction to continue characterization by using LC-MS to confirm the molecular weight and fragmentation of the molecule compound.

Fraction 1 has a retention time (rt) at $4.44 \mathrm{~min}$ (Figure 2) and fraction 2 has rt at 6.97 min (Figure 3). The separation results of fraction 1 and 2 with HPLC are known to have different retention times compared with cyanidin 3-O-glucoside as standard compound at $3.78 \mathrm{~min}$. Based
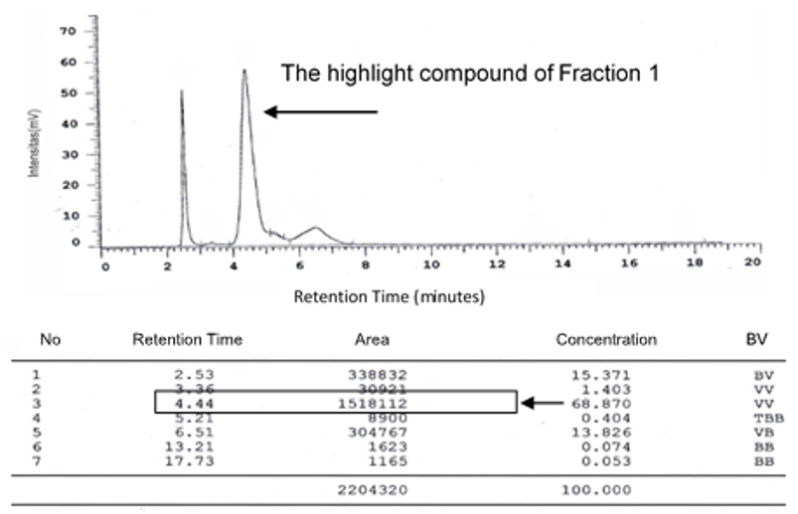

FIGURE 2 A typical chromatogram of fraction 1 separation with HPLC (retention time shown by the arrow direction). 


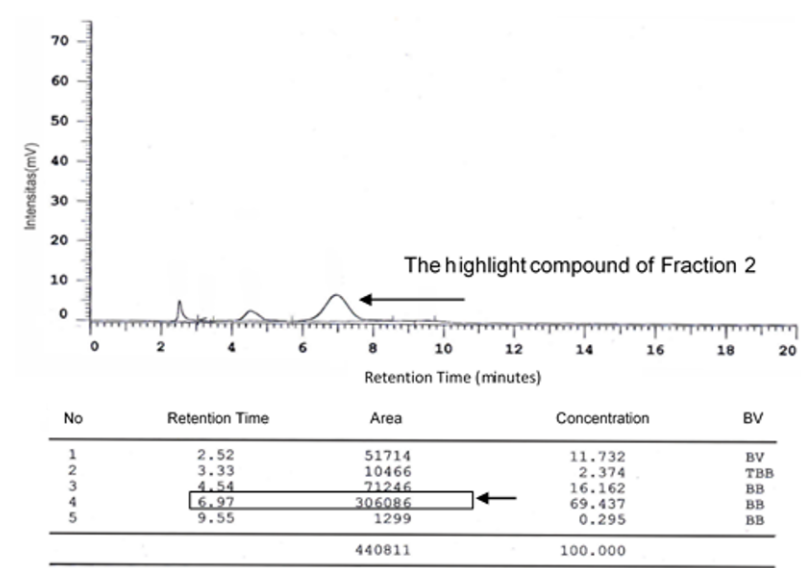

FIGURE 3 A typical chromatogram of fraction 2 separation with HPLC (retention time shown by the arrow direction).

on these results, the examination of fraction 1 is continued by using LC-MS. Confirmation of the peak in fraction 1 was carried out using LC-MS ESI positive ion mode. The LC-MS was eluted with methanol and $6 \%$ formic acid.

This study used LC-MS with ESI positif ion mode, the molecular data is $[\mathrm{M}+\mathrm{H}]^{+}$and fragmented ion molecular is $[\mathrm{M}+\mathrm{H}-\mathrm{X}]^{+}$. Based on the result from fragmentation of fraction 1 compared with X-calibur library data on the LC-MS instrument and data from another research of black rice can be seen in Table 2. The spectrum of fraction 1 has four main ion molecules that are $\mathrm{m} / \mathrm{z} 287.0518$ (55\%); m/z 306.9616 (63\%); m/z 326.0408 (100\%); and $\mathrm{m} / \mathrm{z} 449.1037$ (27\%). The molecular weight of fraction 1 is indicated as $\mathrm{m} / \mathrm{z} 449.1037$, while the theoretically cyanidin 3-O-glucoside compound is $\mathrm{m} / \mathrm{z} 449.1078$. This study confirmed that the specific spectrum of cyanidin 3O-glucoside is $\mathrm{m} / \mathrm{z} 449$ and $\mathrm{m} / \mathrm{z} 287$, and showed that the fraction 1 has a specific spectrum of cyanidin 3-Oglucoside such as the theoretical specific spectrum. Based on the molecular weight and fragment ions shown, fraction 1 can be identified as cyanidin 3-O-glucoside $(\mathrm{m} / \mathrm{z} 287$ ion fragment cyanidin aglycon and m/z 449 molecular weight cyanidin 3-O-glucoside). The cyanidin 3-O-glucoside in the glucoside or sugar compound is hexose ( $\mathrm{m} / \mathrm{z} 162)$. The fragment of hexose in this compound was $\mathrm{m} / \mathrm{z} 306.9616$ (63\%) and m/z 326.0408 (100\%).

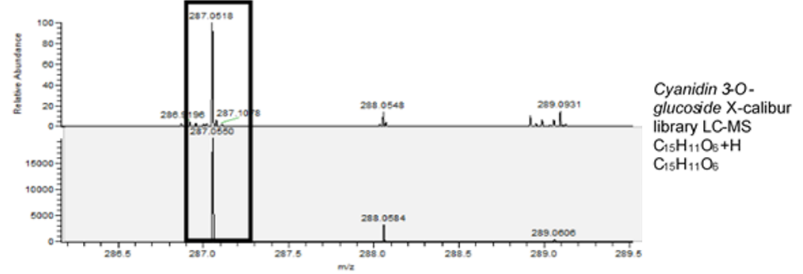

FIGURE 4 Confirmation of ion peak at molecular weight $\mathrm{m} / \mathrm{z} 449$ in LC-MS spectrum.

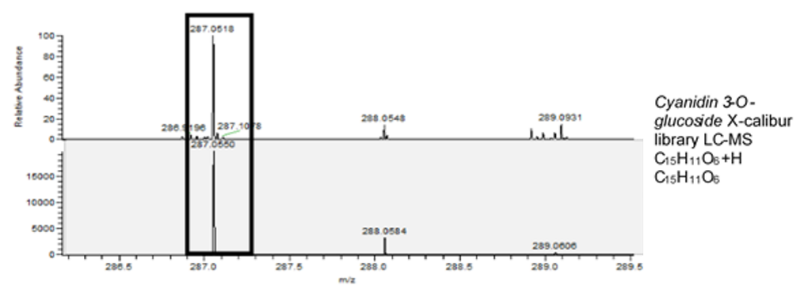

FIGURE 5 Confirmation of fragmented ion peak at $\mathrm{m} / \mathrm{z} 287$ in LCMS spectrum.

It can be confirmed that cyanidin 3-O-glucoside is the main compound in fraction 1 of methanolic extract of black rice bran 'Cempo Ireng'. This characterization process was done with a LC-MS instrument by comparing the molecular weight $(\mathrm{m} / \mathrm{z})$ of each fraction with theoretical molecular weight $(\mathrm{m} / \mathrm{z})$ from data base LC-MS instrument, and presented in Table 2 . This present study suggests that the molecular weight $(\mathrm{m} / \mathrm{z})$ of fraction 1 is 449.1037 and the theoretical ion $\mathrm{m} / \mathrm{z}$ of Cyanidin 3-O-glucoside compound is 449.1078 (Figure 4). Based on the LC-MS spectrum with ion confirmation through ion fragmentation, the information of fraction 1 has fragmented ion in $\mathrm{m} / \mathrm{z} 287$ with molecular weight $\mathrm{m} / \mathrm{z} 449$, as is shown in Figure 5 .

Kim et al. (2008) and Lee (2010) suggested that confirmation of ion peak based on molecular weight of cyanidin 3-O-glucoside is $\mathrm{m} / \mathrm{z} 449$ and ion fragmentation of molecular weight of cyanidin is $\mathrm{m} / \mathrm{z} 287$. Meanwhile, Kim et al. (2008) and Yoshimura et al. (2012) reported that fragmentation of cyanidin 3-O-glucoside showed the loss of hexose. Hexose is a sugar compound with molecular weight $\mathrm{m} / \mathrm{z}$ of 162 . Based on these results of structural characterization using LC-MS, it can be concluded that the fraction 1 is thought to be cyanidin 3-O-glucoside or a compound

TABLE 2 Identification of mass spectrum on fraction 1 using LC-MS.

\begin{tabular}{|c|c|c|c|c|c|c|c|}
\hline \multirow[t]{2}{*}{ Name } & \multirow{2}{*}{$\begin{array}{l}\text { Retention } \\
\text { time (min) }\end{array}$} & \multicolumn{3}{|c|}{ Ion Molecule $[\mathrm{M}]^{+}(\mathrm{m} / \mathrm{z})$} & \multicolumn{3}{|c|}{ Ion Fragment $[\mathrm{M}-\mathrm{X}]^{+}(\mathrm{m} / \mathrm{z})$} \\
\hline & & Experiment & $\begin{array}{l}\text { Software } \\
\text { Xcalibur } \\
\text { library }\end{array}$ & $\begin{array}{l}\text { Other } \\
\text { research* }\end{array}$ & Experiment & $\begin{array}{l}\text { Software } \\
\text { Xcalibur } \\
\text { library }\end{array}$ & $\begin{array}{l}\text { Other } \\
\text { research* }\end{array}$ \\
\hline Fraction 1 & 1.23 & 449.10 & 449.10 & 449.00 & 287.00 & 287.00 & 287.00 \\
\hline $\begin{array}{l}\text { Standard of } \\
\text { Cyanidin 3-O- } \\
\text { glucoside }\end{array}$ & 1.28 & 449.10 & 449.10 & & 287.00 & 287.00 & \\
\hline
\end{tabular}

*Other research (Kim et al. 2008; Lee 2010) 
TABLE 3 The activity of free radical scavenging.

\begin{tabular}{llll}
\hline No. & $\begin{array}{l}\text { Concentration } \\
(\mu \mathrm{g} / \mathrm{mL})\end{array}$ & $\begin{array}{l}\text { Fraction 1 } \\
\text { Activity }(\%)\end{array}$ & $\begin{array}{l}\text { Fraction 2 } \\
\text { Activity }(\%)\end{array}$ \\
\hline 1. & 50 & 27.88 & 25.66 \\
2. & 100 & 39.97 & 34.41 \\
3. & 250 & 61.59 & 62.74 \\
4. & 500 & 81.46 & 80.79 \\
\hline
\end{tabular}

in which the sugar bound is hexose. The concentration of cyanidin 3-O-glucoside in the black rice brand 'Cempo Ireng' is obtained as $76.78 \pm 12.37 \mathrm{ppb}$.

\subsection{The activity of radical scavenging assay against 2.2-diphenyl-1-picrylhydrazyl (DPPH)}

In the 2.2-diphenyl-1-picrylhydrazyl (DPPH) assay (Table 3), fraction 1 had $\mathrm{IC}_{50} 200.96 \mu \mathrm{g} / \mathrm{mL}$, while fraction 2 had $\mathrm{IC}_{50} 218.36 \mu \mathrm{g} / \mathrm{mL}$. In this study's antioxidant activity we used $\mathrm{IC}_{50}$ as a parameter. The concentrations of $\mathrm{IC}_{50}$ explain how particular radical scavenging can inhibit the free radical by as much $50 \%$.

A previous study reported that coloured rice in Korea has antioxidant activity $\left(\mathrm{IC}_{50}\right)$ for 'Heungjinju', 'Shintiheugmi' and Heungseol, 246.9, 287.39 and $381.33 \mu \mathrm{g} / \mathrm{mL}$ respectively (Seo et al. 2011). In accordance with this study, the black rice brand 'Cempo Ireng' has an antioxidant activity $\left(\mathrm{IC}_{50}\right.$ ) of fraction 1 and fraction 2, i.e. $200.960 \mu \mathrm{g} / \mathrm{mL}$ and $\mathrm{IC}_{50} 218.361 \mu \mathrm{g} / \mathrm{mL}$ respectively. The reducing power of inhibiting free radical activity can be compared with synthetic antioxidants, according to Park et al. (2008). The study used BHT, BHA and $\alpha-$ tocopherols at $100 \mu \mathrm{g} / \mathrm{mL}$ scavenging activity is $64.61 \%$; $69.67 \%$ and $32.68 \%$ respectively. It could be suggested that black rice brand 'Cempo Ireng' is an important nutritional food source for human health.

\subsection{Analysis of macro- and micronutrients}

The analysis of macronutrients in this study was to measure reducing and non-reducing carbohydrates (total carbohydrates), and proteins, and lipids which are $9.86 \pm$ $1.11 \% ; 12.56 \pm 1.49 \% ; 11.65 \pm 0.27 \%$; and $10.84 \pm 0.09 \%$ respectively. The micronutrients are composed of minerals Ca, P, Fe with the levels of $38.45 \pm 1.86$ ppm; 22,565.5 \pm 2.314 ppm; $91.46 \pm 4.07$ ppm, respectively (Table 4).

Carbohydrate especially glucose is a main energy source for the human body. Simple carbohydrates are digested faster than complex carbohydrates. Proteins are the main structural component of the human body and also act as enzymes of metabolic reactions in the body. This study showed that protein content is $11.65 \pm 0.26 \%$ which is higher than the protein content in white rice (8\%) (Haryadi 2008). Lipid content in black rice bran in this study is $10.84 \pm 0.09 \%$. Meanwhile, lipid content in black rice bran from Japan is $15 \%$, and $3.8 \%$ of it is oryzanol. Oryzanol is a potential compound to reduce total choles-
TABLE 4 Macro- and micronutrient content of BRB 'Cempo Ireng'.

\begin{tabular}{llr}
\hline No. & Macro- and micronutrients & Content \\
\hline 1. & Reducing carbohydrates (\%) & $12.56 \pm 1.49$ \\
2. & Non-reducing carbohydrates (\%) & $9.86 \pm 1.11$ \\
3. & Amilosa (\%) & $2.27 \pm 0.09$ \\
4. & Proteins (\%) & $11.65 \pm 0.27$ \\
5. & Lipids (\%) & $10.85 \pm 0.09$ \\
6. & Phosphor (P) (ppm) & $22,565.50 \pm 2.30$ \\
7. & Ferrum (Fe) (ppm) & $91.46 \pm 4.07$ \\
8. & Calcium (Ca) (ppm) & $38.45 \pm 1.86$ \\
\hline
\end{tabular}

Note: Water content was $8.65 \%$.

terol in blood plasma (Zawistowski et al. 2009).

Calcium and phosphor are the dominant minerals related in bone and tooth formation and it is important in muscle contraction. The iron mineral is important for heme formation in red blood cells (Soetan et al. 2010). Overall, this study of macro- and micronutrients of BRB 'Cempo Ireng' suggested that this material can be used as a staple food which is good enough for protein, lipid and mineral sources.

\section{Conclusions}

This study concludes that fraction 1 of the methanolic extract of black rice bran contains cyanidin 3-O-glucoside, in which the glucoside is hexose. The activity of fraction 1 and 2 of the methanolic extract of this rice bran against DPPH free radical scavengers has a similar antioxidant activity. The nutrient content of black rice bran 'Cempo Ireng' for total carbohydrate, proteins, lipids, minerals Ca, $\mathrm{P}$ and $\mathrm{Fe}$ are comparable with other rice.

\section{Acknowledgments}

This work was supported by The Ministry of Research, Technology and Higher Education of the Republic of Indonesia under the National Research Competitive Projects.

\section{Authors' contributions}

$\mathrm{R}$, YAP designed the study. AP carried out the laboratory works. AP, R, RP, YAP, WAST analyzed the data and wrote the manuscript. All authors read and approved the final version of the manuscript.

\section{Competing interests}

The authors declare no competing interest.

\section{References}

Abdel-Aal ESM, Young JC, Rabalski I. 2006. Anthocyanin composition in black, blue, pink, purple, and 
red cereal grains. J Agric Food Chem. 54(13):46964704. doi:10.1021/jf0606609.

Brand-Williams W, Cuvelier ME, Berset C. 1995. Use of a free radical method to evaluate antioxidant activity. LWT - Food Sci Technol. 28(1):25-30. doi:10.1016/S0023-6438(95)80008-5.

Haryadi. 2008. Teknologi Pengolahan Beras. Yogyakarta, Indonesia: Gadjah Mada University Press.

Hyun JW, Chung HS. 2004. Cyanidin and malvidin from Oryza sativa cv. Heugjinjubyeo mediate cytotoxicity against human monocytic leukemia cells by arrest of G2/M phase and induction of apoptosis. J Agric Food Chem. 52(8):2213-2217. doi:10.1021/jf030370h.

Ichikawa H, Ichiyanagi T, Xu B, Yoshii Y, Nakajima M, Konishi T. 2004. Antioxidant activity of anthocyanin extract from purple black rice. J Med Food. 4(4):211218. doi:10.1089/10966200152744481.

Juliano BO, editor. 1985. Rice: Chemistry and Technology. American Association of Cereal Chemists.

Kikuzaki H, Hisamoto M, Hirose K, Akiyama K, Taniguchi H. 2002. Antioxidant properties of ferulic acid and its related compounds. J Agric Food Chem. 50(7):2161-2168. doi:10.1021/jf011348w.

Kim MK, Kim Ha, Koh K, Kim HS, Lee YS, Kim YH. 2008. Identification and quantification of anthocyanin pigments in colored rice. Nutr Res Pract. 2(1):46-49. doi:10.4162/nrp.2008.2.1.46.

Kristamtini, Purwaningsih H. 2009. The use of Yogyakarta local black rice as functional foods source. Sukamandi: Balai Besar Penelitian Tanaman Padi. p. 1271.

Kristamtini, Taryono, Basunanda P, Murti RH, Supriyanta, Widyayanti S, Sutarno. 2012. Morphological of genetic relationships among black rice landraces from Yogyakarta and surrounding areas. ARPN J Agric Biol Sci. 7:982-989.

Lee J, Durst RW, Wrolstad RE. 2005. Determination of total monomeric anthocyanin pigment content of fruit juices, beverages, natural colorants, and wines by the $\mathrm{pH}$ differential method: collaborative study. J AOAC Int. 88(5):1269-1278.

Lee JH. 2010. Identification and quantification of anthocyanins from the grains of black rice (Oryza sativa l.) varieties. Food Sci Biotechnol. 19(2):391-397. doi:10.1007/s10068-010-0055-5.

Park YS, Kim SJ, Chang HI. 2008. Isolation of anthocyanin from black rice (Heugjinjubyeo) and screening of its antioxidant activities. J Microbiol Biotechnol. 36:55-60.

Pratiwi R, Purwestri YA. 2017. Black rice as a functional food in Indonesia. Funct Foods Health Dis. 7(3):182194.

Pratiwi R, Purwestri YA, Tunjung WAS. 2014. Effect of diet rice pellets (Oryza sativa l.) 'Cempo Ireng', 'Cempo Abang', and 'IR-64' to lipid serum profile of white rat (Rattus norvegicus Berkenhout, 1769) hyperlipidemia. Yogyakarta, Indonesia. p. 12-18.

Pratiwi R, Tunjung WAS, Rumiyati R, Amalia AR. 2015. Black rice bran extracts and fractions containing cyanidin 3-glucoside and peonidin 3glucoside induce apoptosis in human cervical cancer cells. Indones J Biotechnol. 20(1):69-76. doi:10.22146/ijbiotech.15271.

Rukmana RM, Soesilo NP, Rumiyati, Pratiwi R. 2016. The effect of ethanolic extract of black and white rice bran (Oryza sativa l.) on cancer cells. Indones J Biotechnol. 21(1):63-69. doi:10.22146/ijbiotech.26814.

Ryu SN, Park SZ, HO CT. 1998. High performance liquid chromatographic determination of anthocyanin pigments in some varieties of black rice. J Food Drug Anal. 6(4):729-736.

Seo WD, Kim JY, Han SI, Ra JE, Lee JH, Song YC, Park MJ, Kang HW, Oh SK, Jang KC. 2011. Relationship of radical scavenging activities and anthocyanin contents in the 12 colored rice varieties in Korea. J Korean Soc Appl Biol Chem. 54(5):693-699. doi:10.1007/BF03253147.

Soetan KO, Olaiya CO, Oyewole OE. 2010. The importance of mineral elements for humans, domestic animals and plants-A review. Afr J Food Sci. 4(5):200222.

Tsuda T, Horio F, Uchida K, Aoki H, Osawa T. 2003. Dietary cyanidin 3-o- $\beta$-d-glucoside-rich purple corn color prevents obesity and ameliorates hyperglycemia in mice. J Nutr. 133:2125-2130.

Xia X, Ling W, Ma J, Xia M, Hou M, Wang Q, Zhu H, Tang Z. 2006. An anthocyanin-rich extract from black rice enhances atherosclerotic plaque stabilization in apolipoprotein E-deficient mice. J Nutr. 136:2220-5.

Yoshimura Y, Zaima N, Moriyama T, Kawamura Y. 2012. Different localization patterns of anthocyanin species in the pericarp of black rice revealed by imaging mass spectrometry. PLoS ONE 7(2):e31285. doi:10.1371/journal.pone.0031285.

Zawistowski J, Kopec A, Kitts DD. 2009. Effects of a black rice extract (Oryza sativa L. indica) on cholesterol levels and plasma lipid parameters in Wistar Kyoto rats. J Funct Foods 1(1):50-56. doi:10.1016/j.jff.2008.09.008. 